\title{
TANGGUNG JAWAB PIDANA, PERDATA DAN ADMINISTRASI ASISTEN PERAWAT DALAM PELAYANAN KESEHATAN DESA SWADAYA
}

\author{
Clara Yunita Ina Ola, Khoirul Huda, Andika Persada Putera \\ Program Studi Magister Ilmu Hukum \\ Fakultas Hukum Universitas Hang Tuah Surabaya \\ J1. Arif Rahman Hakim 150, Surabaya, Jawa Timur, 60111 \\ E-mail : clarayunitainaola@gmail.com
}

\begin{abstract}
This study analyzes the accountability of nurse's assistant in performing health service practices of people in swadaya village. This research uses a statue approach and conceptual approach. The act of health service which is often given by nurse's assistant to people in swadaya village is one form of health service which is done outside of the authority that should be done by the authorities in accordance with the rules and applicable law. The unequal distribution of health workers necessitates the nurse's assistant in performing medical practice to perform medical action so that it requires clear legal protection. nurse's assistant in performing acts outside of their authority have legal responsibility. The results showed that nurse's assistant in doing the practice outside of its authority to people in swadaya village can be held accountable of criminal, civil and administrative law, therefore it is expected for the government to be able to create policies or regulations so that in the legislation can be explained about the protection of law and legality for nurse's assistant in swadaya village, so there is a legal force for nurse's assistant in doing health service.
\end{abstract}

\section{Keywords: Legal Liability, Authority, Nursing Assistant, Swadaya Village.}

\begin{abstract}
Abstrak
Penelitian ini menganalisis tentang pertanggungjawaban asisten perawat dalam melakukan praktik pelayanan kesehatan masyarakat desa swadaya. Penelitian ini merupakan penelitian hukum normatif menggunakan pendekatan perundang-undangan (statue approach) dan pendekatan konseptual (conceptual approach). Tindakan pelayanan kesehatan yang sering diberikan asisten perawat kepada masyarakat desa swadaya merupakan salah satu bentuk pelayanan kesehatan yang dilakukan diluar dari kewenangannya yang seharus dilakukan oleh yang berwenang sesuai dengan peraturan dan Undang-Undang yang berlaku. Tidak meratanya penyebaran petugas kesehatan maka mengharuskan asisten perawat dalam melakukan praktik pelayanan kesehatan melakukan tindakan medik sehingga membutuhkan perlindungan hukum yang jelas. Asisten perawat dalam melakukan tindakan diluar dari kewenangannya mempunyai tanggungjawab hukum. Hasil penelitian menunjukan bahwa asisten perawat dalam melakukan praktik diluar kewenangannya pada masyarakat desa swadaya dapat diminta pertanggungjawaban hukum pidan, perdata dan adminstrasi, oleh karena itu sangat diharapkan bagi pemerintah untuk dapat membuat kebijakan atau regulasi sehingga dalam peraturan perundang-undangan dapat dijelaskan mengenai perlindungan
\end{abstract}


hukum dan legalitas bagi asisten perawat di desa swadaya, sehingga adanya kekuatan hukum bagi asisten perawat dalam melakukan pelayanan kesehatan.

\section{Kata kunci: Pertanggungjawaban Hukum, Kewenangan, Asisten Perawat, Desa Swadaya}

\section{A. PENDAHULUAN}

Undang-Undang Dasar 1945 pada Pasal 28H ayat (1) mengatur bahwa setiap orang berhak hidup sejahtera lahir dan batin, bertempat tinggal, dan mendapatkan lingkungan hidup yang baik dan sehat serta berhak memperoleh pelayanan kesehatan. Untuk mewujudkan hakikat dari Pasal $28 \mathrm{H}$ diatas, maka pemerintah mengeluarkan Undang-Undang Republik Indonesia Nomor 36 Tahun 2009 selanjutnya disingkat Undang-Undang Kesehatan menyatakan bahwa : setiap orang mempunyai hak dalam memperoleh pelayanan kesehatan yang aman, bermutu dan terjangkau. Oleh karena itu setiap individu, keluarga dan masyarakat berhak memperoleh perlindungan terhadap kesehatannya, dan negara bertanggung jawab mengatur agar terpenuhi hak hidup sehat bagi penduduknya.

Berdasarkan Undang-Undang Nomor 36 Tahun 2014 tentang Tenaga Kesehatan, tenaga kesehatan merupakan setiap orang yang mengabdikan diri dalam bidang kesehatan serta memiliki pengetahuan dan atau keterampilan melalui pendidikan dibidang kesehatan untuk jenis tertentu memerlukan kewenangan untuk melakukan upaya kesehatan. Berdasarkan Rencana Pembangunan Jangka Menengah (RPJM) 2010 sampai 2014 pemerintah menetapkan setidaknya terdapat 183 jumlah kabupaten yang tergolong daerah tertinggal, dari jumlah tersebut sebanyak 128 kabupaten atau sekitar 62\% berada di wilayah kawasan timur Indonesia (KTI). Ketertinggalan kabupaten tersebut diklasifikasikan menjadi 5 (lima) kelompok yaitu : tidak tertinggal atau maju, agak tertinggal, tertinggal, sangat tertinggal dan sangat parah. Provinsi NTT menempati urutan ketiga daerah tertinggal.

Kabupaten yang tertinggal seperti Timor Tengah Utara, Alor, Lembata, Flores Timur, Sikka, Ende, Ngada, Rote, Sumba Barat. Kabupaten dengan katagori sangat tertinggal Sumba Timur, Kupang, Timor Tengah Selatan, Belu, Manggarai Barat. Kabupaten yang mempoleh katagori kabupaten sangat parah adalah Manggarai Timur, Nagekeo, Sabu Raijua, Sumba Barat Daya, Sumba Tengah. Terlepas dari data tersebut, jika diuraikan secara mendetail, ketertinggalan suatu daerah lebih diakibatkan karena letaknya secara geografis relatif terpencil, sulit dijangkau dan jauh di pedalaman, potensi sumber daya alam relatif kecil atau belum dikelola secara maksimal, kuantitas sumber daya manusia relatif sedikit dengan kualitas yang relatif rendah, kondisi infrastruktur sosial ekonomi kurang memadai, kegiatan investasi dan produksi yang rendah dan beberapa daerah yang merupakan daerah perbatasan antar negara, rawan bencana alam dan rawan konflik, baik secara vertikal maupun horizontal.

Daerah pedalaman merupakan salah satu wujud dari ketertinggalan suatu daerah. Sudah menjadi hal yang biasa bagi masyarakat daerah pedalaman dengan kondisi yang serba terbatas. Upaya kesehatan di Indonesia belum terselenggara secara menyeluruh, terpadu dan berkesinambungan, berbagai upaya penyelenggaraan kesehatan yang bersifat optimal penting 
untuk diselenggarakan dengan pendekatan promotif, preventif, kuratif dan rehabilitatif yang dijalankan secara komprehensif masih dirasa kurang ${ }^{1}$. Keberhasilan upaya kesehatan salah satunya tergantung pada ketersediaan sumber daya kesehatan yang berupa tenaga kesehatan ${ }^{2}$.

Namun jumlah sumber daya manusia kesehatan masih belum memadai, rasio tenaga kesehatan dengan jumlah penduduk masih rendah ${ }^{3}$. Oleh karena itu pada Provinsi Nusa Tenggara Timur (NTT) khususnya desa swadaya masih ada asisten perawat yang sebenarnya bertugas sebagai tenaga kesehatan namun dalam pelayanan kesehatan dan praktik kesehatan, asisten perawat juga melakukan pelayanan berupa tindakan medis yang sebenarnya bukan kewenangan dari asisten perawat, namun hal ini masih tetap berlangsung sampai sekarang dikarenakan hanya asisten perawat saja yang berada di desa tersebut dan juga adanya dukungan dan kepercayaan penuh dari masyarakat desa swadaya sehingga lebih memilih asisten perawat untuk menangani setiap penyakit atau keluhan kesehatan yang dialami mereka.

Selain itu, ada faktor lain yaitu mayarakat berpandangan bahwa asisten perawat adalah tenaga kesehatan yang fleksibel dimana bila masyarakat berkunjung ke rumah untuk pemeriksaan tidak terlalu ribet, pelayanan yang ramah, dapat melayani pasien di rumah pasien dan juga harga pengobatan yang terjangkau oleh masyarakat ${ }^{4}$.

Pada undang-undang maupun Peraturan Menteri Kesehatan tidak memuat tentang asisten perawat dapat memberikan pelayanan diluar kompetensi atau keilmuannya, hanya pada Undang-Undang Kesehatan memuat tentang asisten perawat adalah bekerja sebagai asisten tenaga kesehatan dan bekerja di bawah supervisi tenaga kesehatan. Kewenangan dan kompetensi saling berkaitan satu sama lain dan tidak bisa dipisahkan. Undang-Undang Tenaga Kesehatan Nomor 36 Tahun 2014 pasal 26 menyatakan banhwa tenaga kesehatan yang telah ditempatkan di Fasilitas Pelayanan Kesehatan wajib melaksanakan tugas sesuai dengan kompetensi dan kewenangannya.

Seiring dengan hak setiap orang untuk mendapatkan layanan kesehatan dimanapun mereka berdomisili dan makin tingginya kebutuhan akan layanan akses kesehatan di desa maka asisten perawat pun berperan aktif dalam memberikan pelayanan kesehatan di masyarakat. Namun dengan semakin kompleksnya masalah kesehatan dan tuntutan masyarakat yang semakin meningkat, secara tidak langsung menuntut asisten perawat untuk melakukan praktik di luar wewenangnya dengan alasan tidak adanya atau kurangnya tenaga medis di desa, pelayanan asisten perawat lebih baik dan juga biaya pengobatan yang terjangkau. Dengan adanya keadaan seperti ini, selain memperberat asisten perawat dalam menjalankan tugasnya, akan menimbulkan dilema tersendiri bagi asisten perawat dalam menjalankan praktik di luar kewenangan dan di luar kompetensi yang dimiliki.

\footnotetext{
${ }^{1}$ Ns. Ta'adi, Hukum Kesehatan Sanksi dan Motivasi Bagi Perawat, Penerbit Buku Kedokteran EGC, Jakarta, 2013, h.7.

2 Sri Praptianingsih, Kedudukan HukumPerawat dalam Upaya Kesehatan di Rumah Sakit, RajaGrafindo Persada, Jakarta, 2006, h.3.

${ }^{3}$ Ns. Ta'adi, Op.Cit., h.8.

${ }^{4}$ Afay, “ Mantri Bisa Jadi Alternatif Pelayanan Kesehatan”, Detiknews, 7 April 2010.
} 
Dengan adanya keadaan yang menuntut asisten perawat untuk melakukan pelayanan diluar kewenangannya dan diluar kompetensinya, secara tidak langsung menimbulkan ketakutan akan adanya pertanggungjawaban hukum dikemudian hari oleh pasien maupun keluarga pasien yang dibebani kepada asisten perawat apabila dalam menjalankan praktik tersebut, asisten perawat melakukan tindakan yang salah dan merugikan pihak pasien.

\section{B. RUMUSAN PERMASALAHAN}

Berdasarkan uraian diatas, penelitian ini bertujuan untuk menjawab permasalahan, berkaitan dengan bagaimana tanggung jawab pidana, perdata dan administrasi asisten perawat dalam pelayanan di desa swadaya?

\section{METODE PENELITIAN}

Tipe penelitian ini merupakan penelitian yuridis normatif yaitu penelitian yang mencari pemecahan atas isu hukum yang timbul untuk memberikan preskripsi ${ }^{5}$ mengenai apa yang seyogyanya atas isu yang diajukan. Dalam penelitian ini, peneliti mengkaji pada norma-norma hukum yang terdapat dalam peraturan perundang-undangan secara sistematis $^{6}$ dan putusan pengadilan yang berkaitan dengan pertanggungjawaban pidana. Pendekatan yang digunakan dalam penelitian ini adalah pendekatan perundang-undangan (statute approach) yaitu pendekatan yang mengkaji tentang asas-asas hukum, norma-norma hukum dan peraturan perundang-undangan serta pendekatan konseptual (conceptal approach) ${ }^{7}$ yaitu mengadakan identifikasi terhadap pengertian-pengertian pokok dasar dalam hukum yakni subyek hukum, hak dan kewajiban, peristiwa hukum, hubungan hukum dan obyek hukum. Bahan hukum dalam penelitian ini terdiri dari bahan hukum primer, bahan hukum sekunder dan bahan hukum tersier.

Dalam proses pengumpulan badan hukum, peneliti menggunakan studi dokumen, yaitu mengumpulkan bahan-bahan hukum kepustakaan yang berupa peraturan perundangundangan, buku-buku hukum, jurnal, literatur, dan kamus hukum , kamus bahasa Indonesia dan buku ajar keperawatan. Adapun langkah-langkah pengumpulan bahan hukum meliputi: membaca, mempelajari, mengutip, menghubungkan bahan-bahan hukum dari bahan hukum primer, bahan hukum sekunder serta bahan hukum tersier sehingga menjadi satu kesatuan sehingga mudah dalam pengelolaannya. Bahan hukum yang berhasil dikumpulkan dan diperoleh untuk penelitian kemudian diolah secara sistematis dan konsisten, selanjutnya dilakukan analisis dalam rangkaian suatu pernyataan-pernyataan yang menggambarkan hasil penelitian yang didasarkan pada masalah yang diteliti. Langkah selanjutnya adalah dilakukan

\footnotetext{
${ }^{5}$ Marzuki Peter Mahmud, Penelitian Hukum, Jakarta : Kencana Prenada Media Group, 2005, h.59-60.

${ }^{6}$ Mertokusumo Sudikno, Penemuan Hukum, Yogyakarta : Liberty, 2007, h.18.

Sistematika adalah: tatanan atau kesatuan yang utuh yang terdiri dari bagian-bagian atau unsur-unsur yang saling berkaitan erat satu sama lain yaitu kaedah atau pernyataan tentang apa yang seharusnya sehingga sistem hukum adalah kumpulan unsur-unsur yang ada dalam interaksi satu sama lain yang merupakan satu kesatuan yang terorganisir dan kerjasama ke arah tujuan kesatuan.

${ }^{7}$ Marzuki, Peter Mahmud, Op.Cit.,h.133.
} 
analisis secara teoritikal terhadap bahan-bahan hukum tersebut guna untuk menemukan, memahami dan menjelaskan pertanggungjawaban pidana, perdata dan administrasi asisten perawat dalam pelayanan kesehatan desa swadaya.

\section{PEMBAHASAN}

Pada bagian ini, dibahas tiga hal berikut ini. Pertama, tanggung jawab pidana asisten perawat dalam pelayanan di desa swadaya; Kedua, tanggung jawab perdata asisten perawat dalam pelayanan di desa swadaya; Ketiga, tanggung jawab administrasi asisten perawat dalam pelayanan di desa swadaya.

\section{Tanggung Jawab Pidana Asisten Perawat Dalam Pelayanan di Desa Swadaya}

Hukum pidana termasuk dalam hukum yang berlaku umum, dimana setiap orang harus tunduk kepada peraturan dan pelaksanaan aturan ini dapat dipaksakan, sehingga setiap anggota masyarakat termasuk asisten perawat harus taat, juga termasuk orang asing yang berada dalam wilayah yurisdiksi Negara Republik Indonesia. Menurut ketentuan yang diatur dalam hukum pidana, bentuk-bentuk kesalahan terdiri dari:

a. Kesengajaan (Dolus) : dalam KUHP dicantumkan kesengajaan adalah kemauan untuk melakukan atau tidak melakukan perbuatan-perbuatan yang dilarang atau diperintahkan oleh undang-undang.

b. Kealpaan ( $\mathrm{Culpa}$ ), pada umumnya kealpaan itu terdiri dari dua bagian, yaitu tidak berhati-hati melakukan suatu perbuatan, disamping dapat menduga akibat perbuatan itu. Namun meskipun suatu perbuatan dilakukan dengan hati-hati masih mungkin juga terjadi kealpaan jika yang berbuat itu telah mengetahui bahwa dari perbuatan itu mungkin akan timbul suatu akibat yang dilarang undang-undang.

Dengan demikian tiap melanggar hukum, baik sengaja maupun tidak sengaja yang sifatnya melanggar, berarti unsur kesengajaan dan kelalaian di sini telah terpenuhi. Selanjutnya agar perbuatan pelanggaran hukum dapat dikatakan telah melakukan perbuatan melawan hukum, akibat dari pelanggaran hukum itu harus membawa kerugian bagi pihak lain. Dalam arti sempit, perbuatan melawan hukum diartikan bahwa orang yang berbuat pelanggaran terhadap orang lain atau ia telah berbuat bertentangan dengan suatu kewajiban hukumnya sendiri. Setiap tindakan medis selalu mengandung resiko, sekecil apapun tindakan medis, dapat saja menimbulkan resiko yang besar sehingga mengakibatkan pasien mengalami kerugian.

Dalam hal terjadi resiko baik yang dapat diprediksi maupun tidak dapat diprediksi, profesi kesehatan tidak dapat dimintakan tanggung jawabnya. Tanggung jawab profesi kesehatan dapat dimintakan apabila berbuat kesalahan atau kelalaian. Dalam dunia kesehatan, tuntutan malpraktik berdasarkan hukum pidana (dengan kata lain sebagai kriminalitas dalam bidang medik) yang tercatat dalam literatur-literatur sebenarnya tidak banyak. Meskipun demikian, perlu diketahui beberapa perbuatan yang dikategorikan dalam malpraktik pidana antara lain: Penganiayaan (Mishandeling), kealpaan yang menyebabkan luka-luka dan kealpaan yang menyebabkan kematian. 
Adami Chazawi menilai tidak semua malpraktik medis masuk dalam ranah hukum pidana. Ada 3 unsur yang harus dipenuhi yaitu: pertama, sikap batin profesi kesehatan (ada kesengajaan atau dolus atau culpa); kedua, tindakan medis yang dilakukan melanggar standar profesi, standar operasional prosedur atau mengandung sifat melawan hukum, tidak sesuai dengan kebutuhan media pasien; ketiga, menimbulkan luka-luka (Pasal 90 KUHP) atau kehilangan nyawa pasien.

Pertanggungjawaban pidana dengan mengedepankan dan menetapkan pelaku tindak pidana sebagai subyek hukum pidana, dalam ketentuan perundang-undangan agar pelaku tindak pidana dapat dipertanggungjawabkan atas segala perbuatan hukum yang dilakukannya sebagai perwujudan tanggung jawab karena kesalahannya terhadap orang lain, dengan dapat dipertanggungjawabkannya subyek hukum pidana tersebut tentunya akan memberikan detteren effect untuk tidak melakukan tindak pidana, sehingga dapat mencegah terjadinya tindak pidana di kemudian hari. Perbedaan mendasar antara tindak pidana biasa dan tindak pidana medis terletak pada fokus tindak pidana tersebut. Fokus tindak pidana biasa terletak pada akibat dari tindak pidana, sedangkan pada tindak pidana medis fokusnya pada sebab atau kausa dari tindak pidana dan pertanggungjawaban pidananya harus dapat dibuktikan tentang adanya kesalahan professional.

Kesalahan dalam tindak pidana medis pada umumnya terjadi karena kelalaian yang dilakukan oleh dokter atau tenaga kesehatan lainnya. Dalam hal ini dapat terjadi karena tenaga kesehatan melakukan sesuatu yang seharusnya tidak dilakukan atau tidak melakukan sesuatu yang harusnya dilakukan. Penentuan tentang ada tidaknya kelalaian dalam pelaksanaan tindakan asisten perawat, harus dilihat secara komprehensif yakni ada tidaknya kompetensi dan kewenangan yang dimiliki seorang asisten perawat, bagaimana seharusnya asisten parawat melakukan tindakan pelayanan kesehatan kepada masyarakat dengan ukuran sikap dan tindakan asisten perawat dalam situasi dan kondisi. Penentuan tingkat kesalahan tentang ada atau tidaknya kelalaian asisten perawat harus dibedakan antara lain $^{8}$ :

a. Masa kerja asisten perawat dengan kemampuan rata-rata ;

b. Fasilitas sarana kesehatan yang tersedia pada waktu dilakukannya tindakan pelayanan kesehatan ;

c. Faktor-faktor penunjang lainnya yang berpengaruh dalam tindakan medis yang telah dilakukan oleh asisten perawat.

Menurut penulis, asisten keperawatan yang melakukan praktik pelayanan kesehatan masyarakat di desa swadaya, hanya dapat dituntut secara pidana apabila terjadi culpa lata yaitu cacat baik permanen maupun tidak dan juga terjadi kematian dalam pelaksanaan pelayanan kesehatan tersebut, selain melakukan culpa lata, menurut penulis asisten perawat dapat dituntut secara pidana apabila ia melakukan perbuatan melawan hukum, dimana dalam menjalankan praktik pelayanannya bertentangan atau tidak sesuai dengan tata atau ketertiban yang dikehendaki oleh hukum yang tertuang dalam peraturan perundang-undangan, dalam hal

\footnotetext{
${ }^{8}$ Bambang Poernomo, Asas-asas Hukum Pidana, Ghalia Indonesia, Yogyakarta, 1994, h. 128.
} 
ini, asisten perawat hanya dapat melakukan praktik pelayanan kesehatan sesuai dengan ketentuan perundang-undangan sehingga nantinya tidak menimbulkan perbuatan melawan hukum yang dapat dituntut pertanggungjawabannya secara pidana.

\section{Tanggung Jawab Perdata Asisten Perawat Dalam Pelayanan di Desa Swadaya}

Pertanggungjawaban hukum dibidang perdata akan bersumber pada perbuatan melawan hukum atau wanprestasi. Namun kedua batasan pelanggaran hukum tersebut tetap tidak akan lepas dari pelaksanaan pelayanan kesehatan asisten perawat. Tindakan asisten perawat dapat dikatan sebagai perbuatan melawan hukum apabila terpenuhinya usur-unsur yang tertuang dalam pasala 1365 KUHPerdata, yakni adanya kerugian nyata yang diderita sebagai akibat langsung dari perbuatan tersebut. Sementara pertanggungjawaban dalam kategori wanprestasi apabila terpenuhi unsur-unsur wanprestasi dalam pasal 1234 KUHPerdata.

Pertanggungjawaban perawat bila dilihat dari ketentuan dalam KUHPerdata maka dapat dikategorikan kedalam 4 (empat) prinsip yaitu sebagi berikut :

a. Pertanggungjawaban dengan asas respondeat superior atau vicarious liability atau let's the master answer maupun the captain of ship melalui Pasal 1367 KUHPerdata, yang menyatakan: "Seseorang tidak hanya bertanggungjawab atas kerugian yang disebabkan perbuatannya sendiri, melainkan juga atas kerugian yang disebabkan perbuatan-perbuatan orang-orang yang menjadi tanggungannya atau disebabkan barang-barang yang berada di bawah pengawasannya" dalam hal ini pertanggungjawaban akan muncul apabila kesalahan terjadi dalam menjalankan tuganya. Sebagai bagian dari tim maupun orang yang bekerja di bawah perintah dokter atau puskesmas, maka asisten perawat akan bersama-sama bertanggung gugat kepada kerugian yang menimpa pasien.

b. Pertanggungjawaban dengan asas Zaakwarneming berdasarkan Pasal 1354 KUHPerdata yaitu "Jika seseorang dengan sukarela tanpa ditugaskan, mewakili urusan orang lain, dengan atau tanpa setahu orang itu, maka ia secara diam-diam mengikatkan dirinya untuk meneruskan serta menyelesaikan urusan itu, Ia harus membebani diri dengan segala sesuatu yang termasuk urusan itu. Ia juga harus menjalankan segala kewajiban yang harus ia pikul jika ia menerima kekuasaan yang dinyatakan secara tegas". Dalam hal ini konsep pertanggungjawaban terjadi seketika bagi seorang asisten perawat yang berada dalam kondisi tertentu harus melakukan pertolongan darurat dimana tidak ada orang lain yang berkompeten untuk itu sehingga asisten perawat menggantikan tugas atau peran dari orang yang seharusnya berkompeten melaksanakan tugas tersebut.

c. Pertanggungjawaban langsung berdasarkan pasal 1365 KUHPerdata "Tiap perbuatan yang melanggar hukum dan membawa kerugian kepada orang lain, mewajibkan orang yang menimbulkan kerugian itu karena kesalahannya untuk mengganti kerugian tersebut" dan pasal 1366 KUHPerdata "Setiap orang bertanggungjawab, bukan hanya atas kerugian yang disebabkan perbuatan-perbuatan, melainkan juga 
atas kerugian yang disebabkan kelalaian atau kesembronoannya". Berdasarkan ketentuan pasal tersebut maka menurut penulis apabila seorang asisten perawat dalam melakukan praktik pelayanan kesehatan tersebut melakukan kesalahan sehingga mengakibatkan kerugian nyata pada pasien dan pasien tersebut menggugatnya maka asisten perawat wajib memikul tanggung jawab perdata secara langsung.

Pertanggungjawaban karena gugatan wanprestasi berdasarkan Pasal 1234 KUHPerdata, dalam wanprestasi seorang asisten perawat akan dimintai pertanggungjawaban apabila terpenuhi unsur-unsur wanprestasi yaitu : Tidak mengerjakan kewajibannya sama sekali; mengerjakan kewajiban tetapi terlambat; mengerjakan kewajiban tetapi tidak sesuai dengan yang seharusnya; mengerjakan yang seharusnya tidak boleh dilakukan;

Menurut penulis berdasarkan Pasal 1234 tersebut, dalam tindakan pemberian pelayanan kesehatan oleh asisten perawat di desa swadaya, penegakan hukum secara perdata dapat dikenakan pada asisten perawat karena telah melakukan wanprestasi yaitu apabila asisten perawat mengerjakan yang seharusnya tidak boleh dilakukan olehnya dalam konteks ini, melakukan pelayanan kesehatan diluar kewenangan dan kompetensi sebagai seorang asisten perawat. Menurut hukum perdata, dasar pertanggungjawaban dibagi menjadi dua macam yaitu pertanggungjawaban atas dasar kesalahan (lilability without based on fault) dan atas dasar resiko atau tanpa kesalahan (lilability without fault) atau dikenal dengan tanggung jawab mutlak (strick liability). ${ }^{9}$

Prinsip dasar pertanggungjawaban atas dasar kesalahan mengandung arti bahwa seorang harus bertanggungjawab karena ia melakukan kesalahan dan merugikan orang lain, sebaliknya prinsip tanggung jawab risiko adalah bahwa konsumen penggugat tidak diwajibkan lagi melainkan produsen tergugat langsung bertanggungjawab sebagai risiko dari usahanya. risiko dalam hal ini selalu dihubungkan dengan kemungkinan terjadi sesuatu yang merugikan yang tidak diduga atau tidak diinginkan. Dengan demikian risiko mempunyai karakteristik yaitu merupakan ketidakpastian atas terjadinya suatu peristiwa dan ketidakpastian bila terjadi akan menimbulkan kerugian. Wujud dari risiko itu bermacam-macam yaitu berupa kerugian atas harta atau kekayaan, penghasilan, misalnya diakibatkan oleh kebakaran, pencurian, pengangguran dan sebagainya; berupa penderitaan seseorang misalnya sakit atau cacat karena kecelakaan. Untuk dapat dipertanggungjawabkan orang yang melakukan perbuatan melawan hukum, menurut pasal 1365 KUHPerdata yaitu ${ }^{10}$ :

a. Perbuatan itu harus melawan hukum (onrechtmatig);

b. Perbuatan itu harus menimbulkan kerugian ;

c. Perbuatan itu harus dilakukan dengan kesalahan (kelalaian);

d. Antara perbuatan dan kerugian yang timbul harus ada hubungan kausal.

Perbuatan melawan hukum harus dibuktikan lebih dahulu adanya dasar malpraktik yang dilaksanakan oleh asisten perawat yaitu adanya kesalahan/kelalaian, ada kerugian yang diderita pasien oleh kesalahan asisten perawat.

\footnotetext{
${ }^{9}$ Ibid., h.49.

${ }^{10}$ Moegni Djojodihardjo, Perbuatan Melawan Hukum, Cetakan I, 1979, h.22.
} 
Suatu kelalaian yang dilakukan oleh asisten perawat dalam mempergunakan keterampilan dan ilmu pengetahuannya untuk mengobati pasiennya disebut sebagai tindakan malpraktik. Kelalaian yang dimaksud adalah sikap kurang hati-hati dimana tindakan yang dilakukan oleh asisten perawat berada di bawah standar pelayanan medis.

\section{Tanggung Jawab Administrasi Asisten Perawat Dalam Pelayanan di Desa Swadaya}

Asisten perawat dikatakan telah melakukan pelanggaran administrasi manakala asisten perawat tersebut telah melanggar hukum administrasi. Perlu diketahui bahwa dalam melakukan police power, pemerintah mempunyai kewenangan menerbitkan berbagai ketentuan di bidang kesehatan, misalnya tentang persyaratan bagi asisten perawat untuk menjalankan tugasnya (surat ijin kerja, surat ijin praktek), batas kewenangan serta kewajiban asisten perawat.

Apabila aturan tersebut dilanggar maka tenaga kesehatan yang bersangkutan dapat dipersalahkan melanggar hukum administrasi. Seperti yang telah dijelaskan diatas bahwa pelanggaran administrasi adalah apabila asisten perawat telah melanggar hukum administrasi. Pelanggaran terhadap hukum administrasi tersebut antara lain seperti asisten perawat tidak mempunyai surat ijin kerja, surat ijin praktek, atau melangar batas kewenangan asisten perawat. Aspek hukum administrasi dalam penyelenggaraan praktik pelayanan kesehatan, setiap asisten perawat yang telah menyelesaikan pendidikan dan ingin menjalankan praktik dipersyaratkan untuk memiliki ijin. Ijin menjalankan praktik memiliki dua makna, yaitu ${ }^{11}$ :

a. Ijin dalam arti pemberian kewenangan secara formil (formeele bevoegdheid) ;

b. Ijin dalam arti pemberian kewenangan secara materil (materieele bevoegdheid).

Pada hakikatnya, perangkat ijin menurut hukum administrasi adalah ${ }^{12}$ :

a. Mengarahkan aktivitas artinya, pemberian ijin (formal atau materil) dapat memberi kontribusi dan standar pelayanan yang harus dipenuhi oleh asisten perawat dalam pelaksanaan praktiknya;

b. Mencegah bahaya yang mungkin timbul dalam pelaksanaan praktik dan mencegah penyelenggaraan praktik pelayanan kesehatan oleh orang yang tidak berhak ;

c. Melakukan proses seleksi yakni penilaian administrasi, serta kemampuan teknis yang harus dipenuhi oleh setiap perawat;

d. Memberikan perlindungan terhadap warga masyarakat terhadap praktik yang tidak dilakukan oleh orang yang memiliki kompetensi tertentu.

Dari sudut bentuknya, ijin diberikan dalam bentuk tertulis, berdasarkan permohonan tertulis yang diajukan. Lembaga yang berwenang mengeluarkan ijin juga didasarkan pada kemampuan untuk melakukan penilaian administratif dan teknis tenaga kesehatan. Pengeluaran ijin dilandaskan pada asas keterbukaan, ketertiban, ketelitian, keputusan yang baik, persamaan hak, kepercayaan, kepatutan dan keadilan. Selanjutnya apabila syarat-syarat

\footnotetext{
${ }^{11}$ Rudi Yulianto, Analisa Terhadap Tindakan Perawat Dalam Melakukan Tindakan Khitan, Tesis, Surabaya, 2017, h. 106.

${ }^{12}$ Ibid., h. 107.
} 
tersebut tidak terpenuhi maka ijin dapat ditarik kembali. Di dalam Undang-Undang Tenaga Kesehatan Tahun 2014, hal mendasar yang berkaitan dengan perizinan yaitu:

a. Digunakan Surat Tanda Registrasi (STR) yang diterbitkan oleh MTKI yang berlaku selama lima tahun ;

b. Untuk mendapatkan Surat Tanda Registrasi, pertama kali dilakukan uji kompetensi oleh organisasi profesi (dengan sertifikat kompetensi) ;

c. Masa berlaku Surat Ijin Praktek sesuai dengan Surat Tanda Registrasi. Dengan kata lain, bila masa berlaku Surat Tanda Registrasi sudah habis maka Surat Ijin Praktek juga habis.

Secara prinsip, pertanggungjawaban hukum administrasi lahir karena adanya pelanggaran terhadap ketentuan hukum administrasi terhadap penyelenggaraan praktik tenaga kesehatan dalam hal ini asisten perawat berdasarkan ketentuan yang berlaku. Undang-Undang Tenaga Kesehatan telah memberikan ketentuan administrasi yang wajib ditaati setiap tenaga kesehatan yakni: Penyelengaraan pelayanan kesehatan berdasarkan kewenangan yang telah diatur, bagi asisten perawat setiap kewenangan sudah dicantumkan dalam Peraturan Menteri Kesehatan tentang Asisten Tenaga Kesehatan. Ketiadaan persyaratan administrasi di atas akan membuat perawat rentan terhadap gugatan malpraktik.

Ketiadaan surat ijin praktik dan surat tanda registrasi dalam menjalankan penyelenggaraan pelayanan kesehatan merupakan sebuah administratif malpractice yang dapat dikenai sanksi hukum. Bentuk Sanksi administrasi yang diancamkan pada pelanggaran hukum adminitarsi ini adalah teguran lisan, teguran tertulis, denda administratif dan pencabutan izin. Berdasarkan Undang-Undang Tenaga Kesehatan, dimana tercantum bahwa setiap asisten tenaga kesehatan harus memiliki Sertifikat Ujian Kompetensi dan Surat Tanda Registrasi untuk dapat menjalankan praktik yang telah ada sebelum di undangkan peraturan ini untuk jangka waktu 6 tahun, dalam hal ini undang-undang keperawatan telah dicatat dalam lembaran negara sehingga telah diberlakukan, maka ketentuan pada pasal 88 berlaku hingga tahun 2020.

Dengan demikian menurut penulis, asisten perawat yang telah melakukan praktik dengan memiliki surat tanda registrasi tidak dapat dikenai sanksi administratif, karena telah dilindungi oleh ketentuan ini. Namun dalam ketentuan tersebut juga telah diuraikan kewenangan berupa tindakan-tindakan yang boleh dilakukan oleh asisten keperawatan meliputi melakukan kebersihan lingkungan keperawatan pasien, meja, tempat tidur, dan kelengkapannya; melakukan personal hygiene pasien termasuk asistensi terhadap pasien; melakukan pencucian peralatan dan melakukan dekontaminasi peralatan keperawatan; membersihkan dan merapihkan alat tenun dan tempat tidur pasien; melakukan asistensi penggantian alat tenun tempat tidur yang ada pasien diatasnya; mengidentifikasi dan melaporkan situasi lingkungan yang dapat membahayakan keselamatan klien atau pasien.

Dengan adanya batasan kewenangan tindakan yang boleh dilakukan asisten keperawatan tersebut, maka akan memperjelas dan mempertegas apabila pada praktiknya asisten keperawatan melakukan pelayanan kesehatan diluar batasan, dapat dimintai 
pertanggungjawaban hukum, misalnya dalam praktek pelayanan kesehatan masyarakat di desa swadaya, asisten keperawatan melakukan tindakan pengobatan dan penegakan diagnosa, maka asisten keperawatan telah melakukan praktik kesehatan diluar kewenangan yang telah disebutkan oleh ketentuan perundang-undangan.

Sehingga dapat disimpulkan bahwa asisten keperawatan dapat dimintai pertanggungjawaban secara pidana, perdata dan administrasi dalam praktik pelayanan yang dilakukannya. Tanggung jawab adalah suatu akibat atas konsekuensi kebebasan seseorang tentang perbuatannya, yang berkaitan dengan etika atau moral dalam melakukan suatu perbuatan. Dasar pertanggungjawaban yaitu adanya kesalahan dan risiko. Prinsip pertanggungjawaban atas dasar kesalahan mengandung arti, bahwa seseorang harus bertanggung jawab karena ia melakukan kesalahan karena merugikan orang lain. Sebaliknya prinsip tanggung jawab risiko adalah perawat tergugat langsung bertanggung jawab sebagai risiko tindakannya.

Aspek pertanggungjawaban secara hukum perdata, seorang asisten perawat dapat diminta pertanggungjawaban secara perdata dan tindakan asisten perawat dapat dikatakan sebagai perbuatan melawan hukum, apabila dari tindakan tersebut terpenuhinya unsu-unsur yang tertuang dalam Pasal 1365 KUHPerdata, adanya kerugian nyata yang diderita sebagai akibat langsung dari perbuatan tersebut. Sementara pertanggungjawaban dalam kategori wanprestasi apabila terpenuhinya unsur-unsur wanprestasi yang terdapat pada Pasal 1234 KUHPerdata.

Aspek pertanggungjawaban hukum pidana, seorang asisten perawat dapat diminta pertanggungjawabannya pada saat terpenuhinya unsur-unsur, antara lain: suatu perbuatan yang bersifat melawan hukum, mampu bertanggung jawab, adanya kesalahan (schuld) berupa kesengajaan (dolus) seperti yang tercantum dalam Pasal 338 KUHP, 340 KUHP, atau karena kealpaan (culpa) yang dimana terdapat pada Pasal 359 KUHP dan 360 KUHP. Sedangkan asisten perawat juga dapat diminta pertanggungjawaban secara administrasi apabila asisten perawat melanggar hukum administrasin seperti tidak mempunyai surat tanda registrasi, surat izin kerja, surat ijin praktik dan melanggar batas kewenangannya.

\section{E. PENUTUP}

Berdasarkan pembahasan mengenai tanggung jawab pidana, perdata dan administrasi asisten perawat dalam pelayanan kesehatan desa swadaya, dapat dismipulkan sebagai berikut :

1. Aspek pertanggungjawaban hukum pidana, seorang asisten perawat dapat diminta pertanggungjawabannya pada saat terpenuhinya unsur-unsur, antara lain: suatu perbuatan yang bersifat melawan hukum, mampu bertanggung jawab, adanya kesalahan (schuld) berupa kesengajaan (dolus) seperti yang tercantum dalam Pasal 338 KUHP, 340 KUHP, atau karena kealpaan (culpa) yang dimana terdapat pada Pasal 359 KUHP dan 360 KUHP;

2. Aspek pertanggungjawaban secara hukum perdata, seorang asisten perawat dapat diminta pertanggungjawaban secara perdata dan tindakan asisten perawat dapat dikatakan sebagai perbuatan melawan hukum, apabila dari tindakan tersebut 
terpenuhinya unsu-unsur yang tertuang dalam Pasal 1365 KUHPerdata, adanya kerugian nyata yang diderita sebagai akibat langsung dari perbuatan tersebut. Sementara pertanggungjawaban dalam kategori wanprestasi apabila terpenuhinya unsur-unsur wanprestasi yang terdapat pada Pasal 1234 KUHPerdata;

3. Aspek pertanggungjawaban secara administrasi apabila asisten perawat melanggar hukum administrasin seperti tidak mempunyai surat tanda registrasi, surat izin kerja, surat ijin praktik dan melanggar batas kewenangannya. Adapun saran yang didapat dari penelitian ini adalah Dinas Kesehatan dan PPNI perlu mengadakan atau membuat program-program pelatihan bagi asisten perawat yang berada di desa swadaya guna meningkatkan ilmu pengetahuan dalam pelayanan kesehatan, pemerataan tenaga kesehatan khususnya pada desa swadaya, sehingga dalam memberikan pelayanan tenaga kesahatan menjalankan tugas sesuai dengan kewenangan dan keahlian yang dimiliki agar terhindar dari risiko kesalahan yang berakibat hukum.

\section{DAFTAR PUSTAKA}

\section{Buku}

Afay, "Mantri Bisa Jadi Alternatif Pelayanan Kesehatan”, Detiknews, 7 April 2010.

Djojodihardjo, Moegni, Perbuatan Melawan Hukum, Cetakan I, 1979.

Poernomo, Bambang, Asas-asas Hukum Pidana, Ghalia Indonesia, Yogyakarta, 1994.

Praptianingsih, Sri, Kedudukan HukumPerawat dalam Upaya Kesehatan di Rumah Sakit, RajaGrafindo Persada, Jakarta, 2006.

Marzuki, Peter Mahmud, Penelitian Hukum, Kencana Prenada Media Group, Jakarta, 2005.

Mertokusumo, Sudikno, Penemuan Hukum, Yogyakarta, 2007.

, Penemuan Hukum, Citra Aditya Bakti, Bandung, 2009.

Ta'adi, Ns., Hukum Kesehatan Sanksi dan Motivasi Bagi Perawat, Penerbit Buku Kedokteran EGC, Jakarta, 2013.

\section{Peraturan Perundang-undangan}

Undang-Undang Republik Indonesia Nomor 36 Tahun 2014 tentang Tenaga Kesehatan. Lembar Negara Republik Indonesia Tahun 2014 Nomor 298, Tambahan Lembar Negara Republik Indonesia Nomor 5607.

Peraturan Menteri Kesehatan (Permenkes) Nomor 80 Tahun 2016 tentang Penyelenggaraan Pekerjaan Asisten Tenaga Kesehatan. Berita Negara Republik Indonesia Tahun 2017 Nomor 123. 
Undang-Undang Republik Indoneia Nomor 38 Tahun 2014 tentang Keperawatan. Lembar Negara Republik Indonesia Tahun 2014 Nomor 307, Tambahan Lembar Negara Republik Indonesia Nomor 5612.

Kitab Undang-Undang Hukum Pidana (KUHAP).

Kitab Undang-Undang Hukum Perdata (KUHPER) 